Review de Debut

\title{
パラジウムナノ粒子を触媒に用いた アリールボロン酸の酸化的カップリング反応
}

小出 太郎

\author{
Oxidative Coupling Reaction of Aryl Boronic Acid \\ by Using Palladium Nano Particle
}

Taro Koide

The oxidative coupling reaction of boronic acids or boronic esters by using palladium nano particle/palladium colloid under mild condition was reported. Various boronic acids were available and highly strained macrocyclic compounds were also synthesized.

遷移金属触媒を用いたクロスカップリング反応は有機 合成の強力なツールとして用いられており，2010年に は Heck 先生, 根岸先生, 鈴木先生がパラジウム触媒を 用いたクロスカップリング反応の開発に対してノーベル 賞を受賞された。なかでも，パラジウム触媒を用いた炭 素-炭素結合形成によるビアリール合成は非常に広く研 究・利用されている。パラジウム触媒を用いたクロス カップリング反応の副生成物としてボロン酸のホモカッ プリング体が生成することは知られてはいたが，これま でそれを利用する研究はあまりなされてこなかった。

本稿では，近年発表されたパラジウムナノ粒子・パラ ジウムコロイドを利用したボロン酸およびボロン酸エス テル同士の酸化的カップリング反応について紹介する。

1. パラジウムコロイドを用いたアリールボロン酸のホ モカップリング

高活性なパラジウムコロイドやナノ粒子を発生させら れるパラジウム源として，パラダサイクル化合物は注目 を集めてきた。パラジウムコロイドの存在はこれまでも TEM や質量分析, 広域 X 線吸収微細構造(EXAFS) な どによって確かめられてきたが1)，単離して触媒反応に 応用された例はなかった。

2017 年, Kapdi らは高い活性を示す HerrmannBeller 錯体 (以下パラダサイクル 1)を用いたジアリール メタノールの合成研究の途上，パラジウムコロイドの発 見・単離に至った $($ スキーム 1,2 2) 。反応系中でのパラ ジウムナノ粒子の生成が示唆されたことから, カップリ ング反応の条件を参考に, 化学量論量のパラダサイクル 1 と 4-クロロベンズアルデヒドを, $\mathrm{K}_{2} \mathrm{CO}_{3}$ 存在下, $80{ }^{\circ} \mathrm{C}$ で反応させたところ, パウダー状の黒色微粒子と してパラジウムコロイドが得られた(スキーム2)。 HRTEM 分析から, 得られた粉末では直径約 $2 \mathrm{~nm}$ の球 状粒子が均一に分布しており，ナノ粒子全体での組成は C: $71.5 \% ， \mathrm{O}: 22.4 \% ， \mathrm{Pd}: 3.4 \%$ であった。X 線吸収から

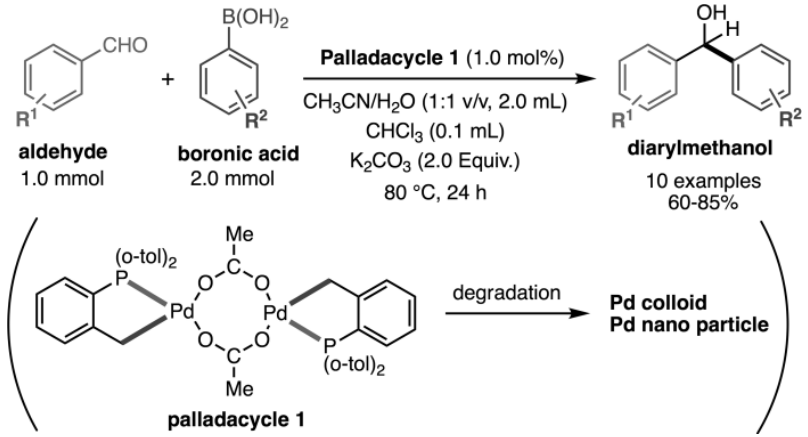

Scheme 1 Palladium-catalyzed diarylmethanol synthesis.

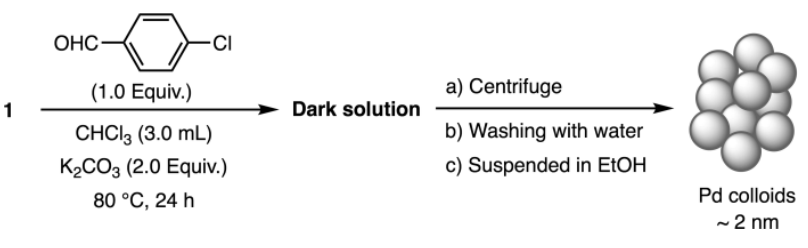

Scheme 2 Active palladium colloid formation from 1.

$\operatorname{Pd}(0)$ および Pd(II)の混合物であることがわかった。

単離されたパラジウムコロイドを利用すると, ボロン 酸同士の酸化的カップリング反応が効率的に進行し, 電 子求引性・供与性置換基を有するアリールボロン酸, へ テロアリールボロン酸, 嵩高いアリールボロン酸, シク ロヘキシルボロン酸のいずれにおいても良好な収率でホ モカップリング体が得られており, その有用性が示され ている(スキーム3)。

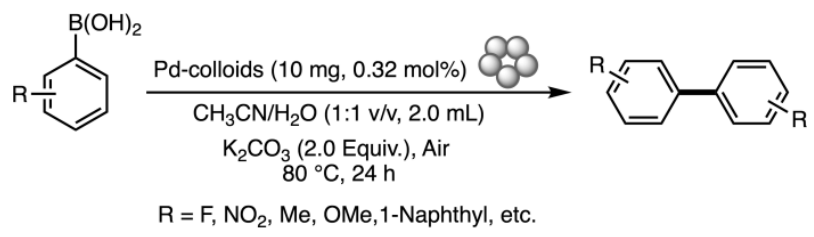

heteroaryl, bulky, and cyclohexyl boronic acids were also available

Scheme 3 Palladium colloids for oxidative homocoupling of aryl boronic acids. 


\section{2. 穏和な条件下でのアリールボロン酸エステルのホモ} カップリングによる高歪み化合物の合成

近年, Jastiらはアリールボロン酸エステル同士の酸 化的カップリング反応によって, シクロパラフェニレン 前駆体となる大きな歪みを持った大環状化合物の合成を 達成している。同じ化合物を合成する際, Sphos Pd G2 を使った分子内鈴木-宮浦カップリングでは低収率でし かマクロサイクルが得られない。一方, 酸素雲囲気下で $\mathrm{PdCl}_{2}\left(\mathrm{PPh}_{3}\right)_{2}$ と KF を用いてボロン酸同士の分子内カッ プリングを行うと，50\%の収率でマクロサイクルが得 られる $(\text { スキーム } 4)^{3.4)}$ 。
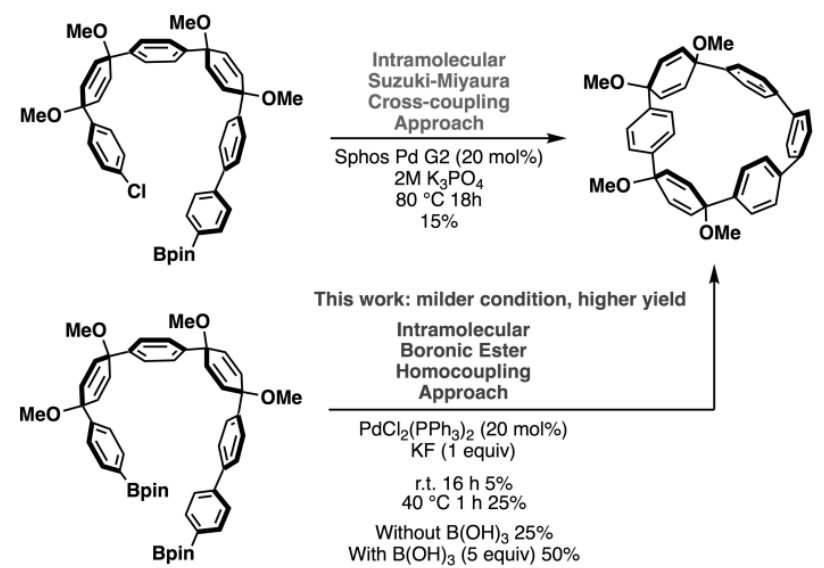

Scheme 4 Optimization and comparison of intramolecular coupling reaction to produce macrocyclic compounds.

このようなボロン酸のホモカップリング反応につい て，フッ化カリウムはボロン酸に配位して活性化しトラ ンスメタル化を促進するためではなく，反応開始段階で パラジウムを 2 価から 0 価に還元するために使われ，そ の後，パラジウム 0 価種が酸素と反応してパラジウムペ ルオキソ種が生成し反応するという機構が Adamo らに よって提唱されていだ)。

Jasti らは反応機構解明のために空気飽和 $\mathrm{THF}-d_{8}$ 中 での NMRによる反応追跡を行った。ボロン酸エステル とパラジウム触媒を溶解させたサンプルに，フッ化カリ ウムを加えても初期段階ではマクロサイクル化の反応は 起きず，まず $\mathrm{PdCl}_{2}\left(\mathrm{PPh}_{3}\right)_{2}$ からの $\mathrm{Pd}(0)$ の生成に伴い, トリフェニルホスフィンオキシドの生成が確認された。 その後, 反応が進行し 12 時間で目的の大環状化合物へ の変換が完了した。パラジウム触媒のみを溶解させた THF 溶液に, フッ化テトラーnーブチルアンモニウム （TBAF）を加えた場合にも，ほぼ定量的なトリフェニル ホスフィンオキシドの生成が確認された。一方でパラジ ウムペルオキソ種の生成は確認されなかった。このこと から，この反応に扔いては，まずホスフィン配位子の酸 化が定量的に進行して配位子をもたないパラジウム 0 価 種が生成することが推測された (スキーム 5)。

NMR 実験と同様の系について動的光散乱法 (DLS) や
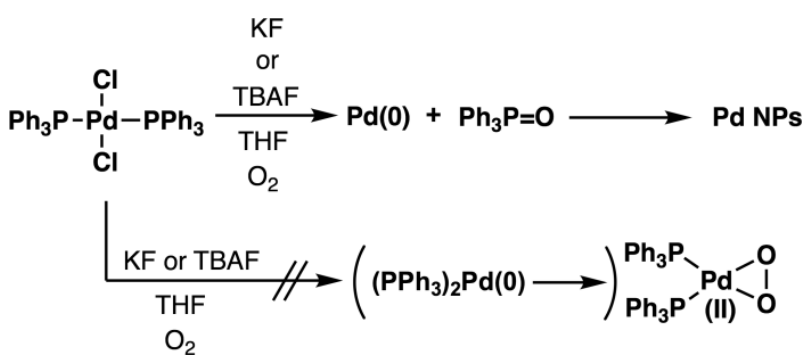

Scheme 5 Proposed mechanism of the initial steps of the reaction.

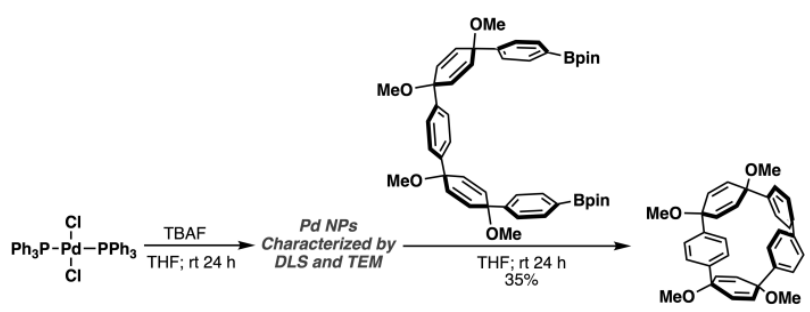

Scheme 6 Synthesis of macrocyclic compounds by using the $\mathrm{Pd}$ nano particle generated in situ.

TEM 観察を行うとパラジウムナノ粒子の生成が確認さ れた。そこにジボロン酸エステルのみを加えると反応が 進行し，目的の大環状化合物が得られた $(ス キ ー ム ~ 6 ~)^{4)}$ 。

これらの結果から, パラジウム源としての触媒に対し， 酸素存在下，フッ素源を加えることによってパラジウム ナノ粒子が生成し，それが反応の活性種として働いてい ることが示唆された。ナノ粒子化することによるパラジ ウム触媒の活性化と，それを用いたカップリング反応に よって, 酸素存在下穏やかな条件で, 通常合成の難しい 化合物の合成も可能になることが示されたといえる。

以上本稿では，パラジウムナノ粒子を活性種とする触 媒反応を取り上げたが，これまでとは異なるアプローチ でのビアリール合成や高歪み化合物の合成が達成され， 今後さらなる応用範囲の拡大とともに詳細な反応機構解 明や触媒性能の向上に期待が持たれる分野である。

文 献

1) D. A. Alonso, C. Najera, Chem. Soc. Rev., 39, 2891 (2010)

2) V. Sable, K. Maindan, A. R. Kapdi, P. S. Shejwalkar, K. Hara, ACS Omega, 2, 204(2017)

3) P. J. Evans, E. R. Darzi, R. Jasti, Nature Chem., 6, 404(2014)

4) E. R. Darzi, B. M. White, L. K. Loventhal, L. N. Zakharov, R. Jasti, J. Am. Chem. Soc., 139, 3106(2017)

5) C. Adamo, C. Amatore, I. Ciofini, A. Jutand, H. Lakmini, J. Am. Chem. Soc., 128, 6829(2006)

(2018 年 3 月 29 日受理)

\begin{tabular}{|l} 
小出太郎 九州大学大学院工学研究院応用化学部 \\
門·助 教士 (理学) \\
〔所属研究室主宰者〕久枝良雄 \\
〔経歴〕2010-12 年日本学術振興会特別研究員 \\
(DC2), 2012 年京都大学大学院理学研究科博士課 \\
程修了, 2012-15 年日本学術振興会特別研究員 \\
(PD) 2015 年 4 月-11 月九州大学先導物質化学研究所博士研究員, \\
2015 年 11 月より現職。〔研究テーマ〕有機合成化学, 構造有機化 \\
学。〔連絡先〕e-mail: koide@mail.cstm.kyushu-u.ac.jp
\end{tabular}

